\title{
Measuring social entrepreneurship and social value with leakage. Definition, analysis and policies for the hospitality industry
}

\author{
Yeamduan Narangajavana ${ }^{1}$. \\ Tomas Gonzalez-Cruz ${ }^{2}$ • \\ Fernando J. Garrigos-Simon ${ }^{3} \cdot$ Sonia Cruz-Ros $^{2}$
}

(C) Springer Science+Business Media New York 2016

\begin{abstract}
The aim is to analyze, define and examine the connections between social entrepreneurship and the generation of social value, considering the concept of leakage as a measure of social value creation and distribution for the hospitality industry. The paper also proposes an exploratory-theoretical framework of policies to promote social entrepreneurship in hospitality, reduce leakage, and increase the generation of social value. Firstly, the paper concentrates on the figure of the social entrepreneur as a promoter of social value creation. Secondly, it analyzes social value creation in hospitality and its measurement. Then, the article studies and presents leakage as an instrument to monitor social value created by social entrepreneurship in hospitality. Finally, the paper proposes a wide framework of policies to enhance social value creation in hospitality, through the reduction of leakage and reinforcement of social entrepreneurship. Leakage is a useful indicator to monitor social value creation in the hospitality industry. The reduction of leakage can gauge the success of policies promoting social
\end{abstract}

Yeamduan Narangajavana

yeamduan@gmail.com

Tomas Gonzalez-Cruz

tomas.gonzalez@uv.es

Fernando J. Garrigos-Simon

fgarrigos@doe.upv.es

Sonia Cruz-Ros

sonia.cruz@uv.es

1 School of Management, Walailak University, 222 Thaiburi, Thasala, Nakhon Si

Thammarat 80160, Thailand

2 Department of Management, University of Valencia, Valencia, Spain

3 Department of Business Organization, Universitat Politecnica de Valencia, Valencia, Spain 
entrepreneurship activities which improve social value creation for the host society. The paper proposes proper and idiosyncratic measures of social value creation in hospitality. It also provides a mechanism to measure the effectiveness of the actions designed to generate social entrepreneurship and social value, at a destination and also at firm or hotel level. A complete framework of actions and policies addressed to increase social entrepreneurship and social value is also proposed.

Keywords Social entrepreneurship · Social value · Leakage

\section{Introduction}

Social Entrepreneurship (SE henceforth) is receiving increased attention in public and private spheres. The economic crisis and the dramatic spending cuts on social services by governments are forcing not-for-profit organizations to face the pressure of covering the gaps left by government, while experiencing a reduction in funding sources. Consequently, individuals and associations are applying entrepreneurial strategies and business models to finance and operate organizations which pursue the mission of creating social value (Chell 2007; Foster and Bradach 2005; Pearce and Doh 2005).

Academically, interest in the field has also increased at an astonishing rate in the last decade - dozens of articles published in top academic journals and special issues devoted to the concept, together with conferences on the topic, bear witness to this interest (Lepoutre et al. 2013; Seelos and Mair 2007). As a result "social entrepreneurship is emerging as an innovative approach for dealing with complex social needs" (Johnson 2000, p.1). But despite the effort deployed by academics around the world and the proliferation of this new line of research, SE as an academic topic is in its infancy (Cohen and Winn 2007), and until recently its development has mainly relied on entrepreneurship literature (Certo and Miller 2008; Dorado 2006; Mair and Martí 2006).

Like entrepreneurship, SE is a fuzzy concept (Hemingway 2005). The concept of SE is still poorly defined (Mair and Martí 2006) and a variety of meanings and contents coexist (Dees 1998). As a consequence, disagreements persist about the domain of entrepreneurship (Zahra and Dess 2001) and adding the value-laden prefix "social" further exacerbates this conceptual debate (Zahra et al. 2009). In addition, SE has moved away from considering differences between Social Entrepreneurs to analyzing differences and specific features of the entrepreneurial process, the impact of different constraints, circumstances and contingent factors and the development of methods to properly assess the amount of social value (SV henceforth) creation (Dorado 2006). However these methods are not consolidated.

In the field of Tourism, despite the recognized relevance of SE for the development of local communities throughout the world, the topic has received scarce attention (Ergul and Johnson 2011; Dzisi and Otsyina 2014). Tourism entrepreneurship, although reduced, has evolved as an academic field of study since the 80s (Carmichael and Morrison 2011). Consequently, there are contributions regarding the characteristics, role, importance, impact, and connections of entrepreneurship in tourism destinations (see Ateljevic 2009; Carmichael and Morrison 2011; Hallak et al. 2012; Koh 2006; Moscardo 2014; Russell and Faulkner 2004; Shaw and Williams 2004; Strobl and 
Peters 2013; Szivas 2001). Nevertheless, although some hospitality corporations are displaying greater awareness of their role in the community and pursuing some aspects of SE (Ergul and Johnson 2011), few studies have dealt directly with the subject of SE in tourism, and specifically in hospitality literature. In addition, the research reports few specific differences to general SE models (Von der Weppen and Cochrane 2012) and underlies the same challenges, namely: refine the definition and hence set limits on the field of study and establish proper performance indicators to measure SV creation (Ho Kang et al. 2010). Moreover, the connections between SE and SV creation in hospitality are very limited. Despite this, in our sector the creation of a SE framework is crucial for the sustainable development of local societies and firms, especially in emerging countries. Sustainable development is development that meets the needs of the present without compromising the ability of future generations to meet their own needs (UN 1987). In this sense, enhancing human living standards while improving the availability of natural resources and ecosystems for future generations is critical (Ergul and Johnson 2011). In our perspective the SV created by the promotion of SE is crucial for sustainability, as we predicate it in the belief that individuals and institutions can be persuaded to accept responsibility for providing not only environmental and economic solutions, but also to solve cultural and social problems.

One has to realize that the sustainability of tourism or hospitality developments must take into account several factors, which depend on the linkages of tourism or hospitality to the host economies and societies, and on the responsibility of individuals and corporations to create SV. In this aspect, the relevance of SE is vital as social entrepreneurs seek to create SV as a main objective, and play a key role as agents of change in the social sector, helping to solve critical social problems (Praszkier and Nowak 2012) or aiding in the creation of sustainable SV (Dees in Praszkier and Nowak 2012).

$\mathrm{SE}$ is critical to overcome a whole range of social problems, such as health, education, environmental destruction, human rights, political and cultural factors, apart from other issues related to economic development; and specific problems such as poverty, unemployment, or even economic development, building a better life for all (Alvord et al. 2004; Bornstein and Davis 2010). This can be explained by them thinking "outside the box" (Martin and Osberg 2007), creating innovative solutions to social problems, and aiming for sustainable socioeconomic development of their environment, through the implementation of innovative ideas, skills, or other resources and capabilities in order to improve people's lives (Alvord et al. 2004; Mulgan et al. 2007).

However, the monitoring of SV promoted by SE, and the creation of appropriate policies to foster SE ventures are two of the greatest remaining challenges for practitioners and researchers in SE, and the field of sustainability. The real problem may not only be measurement per se, but how the measurements may be used to "quantify" the performance and impact of SE, and to promote a positive impact. Many consider very difficult to quantify socio-economic, environmental and social effects. As Emerson (2003, p.40) points out, "for many of those active in the social sector, it has been accepted that most elements of social value stand beyond measurement and quantification". Yet it is necessary to make major efforts in this direction and to develop useful and meaningful measurements which capture the impact of SE and reflect the objectives pursued (Certo and Miller 2008; Mair and Martí 2006; Murphy 
and Coombes 2009), and also to translate these measurements into specific and concrete policies which can enhance SV.

In order to fill these gaps, and after the methodology, this paper devotes the second section to introducing the concept of SE and SV and the distinctive features and challenges surrounding them. In the third section, it shows the state of the art regarding how to define and measure SV creation in the tourism and hospitality industry, taking into consideration the heterogeneity of goals and the complex mix of financial, social and environmental objectives pursued by SE. The paper presents the concept of leakage, defined as the amount of revenue generated by tourists, which does not remain in the destination's economy (Garrigos et al. 2015), as one important indicator to monitor the SV created by SE in the case of touristic, and specifically hospitality ventures, also indirectly measuring the levels or promotion of SE in these firms. Finally, the paper proposes a complete framework of policies aimed at reducing leakage, and promoting SE and SV in destinations, and therefore, enhancing the sustainability of the hospitality developments.

\section{Methodology}

Due to the conceptual nature of the present paper it is worth making the criteria applied to review the relevant literature explicit, and build a strong rationale about the issues to be analyzed. To gain greater understanding of the SE literature, we identified and analyzed the body of articles published in leading management, tourism and entrepreneurship journals in which the primary topic of interest was related to SE or the SE phenomena. Therefore, we searched for articles which explicitly mentioned SE and social entrepreneur, without placing boundaries on the time period. Given that SE is a relatively recent research stream, we wanted to explore every article on the subject and, hence, examined every possible year.

This body of literature consisted of scholarly outlets in management and entrepreneurship as examined by Tahai and Meyer (1999) and Busenitz et al. (2003). Management journals included are: Academy of Management Journal, Academy of Management Review, Administrative Science Quarterly, Journal of Management, Management Science, Organization Science, and Strategic Management Journal. Dedicated entrepreneurship journals included: Entrepreneurship Theory and Practice, Journal of Business Venturing, and Strategic Entrepreneurship Journal. This analysis revealed only eight articles; one was published in Academy of Management Review, one in Academy of Management Journal, two in Strategic Entrepreneurship Journal, and four in Entrepreneurship Theory and Practice. We then expanded our search to other research-oriented journals in business and other fields using the EBSCO, Web of Knowledge, ABI/INFORM, and Science Direct databases for peer-reviewed scholarly articles, again allowing for all years available in each database. Specifically we concentrated on the main journals of tourism, hospitality and leisure, according to the Web of Knowledge. This expanded search yielded 152 articles from a variety of scholarly disciplines including, but not limited to, management, entrepreneurship, tourism and hospitality with the first article appearing in 1991. This constitutes the sample used for our coding scheme, content analysis and concept building, which are found in the following paragraphs. 


\section{Social entrepreneurship and social value: concept, distinctive features and challenges}

The definition of SE remains under discussion in the academic arena. This epigraph does not intend to offer a new concept nor provide a new view, but to cast an eye at the different definitions considering their broadness and the unit of analysis considered, and to analyze the concept of SE and SV creation. Next, the distinctive characteristics of entrepreneurship and the critical differences due to the qualifying adjective 'social' are listed. Likewise, SV creation is considered as the main distinctive feature which is intrinsically associated with SE, and SV definition and measurement as critical challenges which remain unsatisfactorily addressed.

Starting with the concept of SE, and following Neck et al. (2009), two main groups of SE conceptualizations can be distinguished. Those focused on the entrepreneur as an individual and those which provide process-based SE definitions. Entrepreneur-centric definitions describe social entrepreneurs as "an individual with innovative solutions to society's most pressing social problems" (Ashoka, in Neck et al. 2009) or as 'society's change agents: pioneers of innovation that benefit humanity' (The Skoll Foundation, in Neck et al. 2009). Peredo and McLean (2006) describe social entrepreneurs as individuals or groups which aim to create $\mathrm{SV}$, show a capacity to recognize and take advantage of opportunities through innovation, accepting an above average degree of risk, and because of their limited resources, mobilize assets and people in pursuing their social venture. From this perspective, social entrepreneurs are concerned with reconfiguring resources in order to achieve specific social objectives, and their success is measured by the extent to which they achieve social transformation (Alvord et al. 2004; Tracey and Phillips 2007). Thus, the only significant difference between entrepreneurship and SE is the priority of social goals in the mission and the amount of SV created.

Process-base definitions focus on SV creating activities. Dees (1998) states that SE plays the role of change agent in the social sector, by: 1) Adopting a mission to create and sustain SV (also in Austin et al. 2006; Certo and Miller 2008; Mair and Martí 2006; Martin and Osberg 2007; MacMillan 2005; Murphy and Coombes 2009; Zahra et al. 2009); 2) Recognizing and relentlessly pursuing new opportunities to serve that mission (also in Certo and Miller 2008; Mair and Martí 2006; Martin and Osberg 2007; Zahra et al. 2009); 3) Engaging in a process of continuous innovation, adaptation, and learning (also in Mair and Martí 2006); 4) Acting boldly without being limited by resources currently at hand (also in Mair and Martí 2006); and 5) Exhibiting heightened accountability to the constituencies served and for the outcomes created. That is, similarly to entrepreneurship, SE involves processes related to opportunity recognition, defining a mission to be achieved through innovative solutions, resource mobilization and accountancy towards different and multiple constituents.

From the consideration of the above definitions a reasonable doubt arises about what really makes SE different from entrepreneurship. In fact, authors like Chell (2007) advocate the integration of both concepts and propose that the definition of entrepreneurship might include the creation of social and economic value. We do not share this reductionist view, even though both concepts share essential elements, SE presents a set of distinctive features requiring differentiated consideration. 
First of all, some essential features are common to both entrepreneurship and SE. Both exhibit risk-tolerance, innovativeness, proactiveness, and resource mobilization competences (Dees 1998; Mort et al. 2003; Peredo and McLean 2006). Also, both excel at searching, sensing and recognizing opportunities (Dees 1998; Mair and Martí 2006). Similarly, in general terms, entrepreneurship and SE are composed of a similar set of activities and processes: opportunity recognition; envisioning a mission to address the opportunity through innovation; and mobilizing assets and people to overcome resource limitation (Alvord et al. 2004; Austin et al. 2006; Dees 1998; Lepoutre et al. 2013; Murphy and Coombes 2009). The question of innovativeness is especially important. Like traditional entrepreneurs, the SE is an innovator who creates new models of SV creation (Chell et al. 2010; Mair and Martí 2006; Peredo and McLean 2006). On the contrary, solutions to social challenges which do not suppose any innovations are outside the SE concept and fall in what could be named as traditional NGO activities (Lepoutre et al. 2013). However, due to the qualifying adjective 'social', SE and Social Enterprises show distinctive features. That is, SE requires specific competences (Tracey and Phillips 2007), involving additional activities and differentiated criteria to carry out the processes listed above.

The first, main difference is related to the nature of the mission concerned with creating SV (Austin et al. 2006). SE addresses a social problem, thus, what entrepreneurs perceive as a barrier or a liability is an opportunity for SE (Murphy and Coombes 2009). This social purpose or cause should be the core of the SE's mission, which must have a clear and explicit social objective (Certo and Miller 2008; Mair and Schoen 2007; Peredo and Chrisman 2006). SE develops products and services which meet human needs related to an underlying range of basic values which are desirable and important in a civilized society and remain unsatisfied by markets or governments (Seelos and Mair 2005). Thus, the primary mission of SE is to create SV for its clients those who receive the value created (Lepoutre et al. 2013).

The second difference has to do with a specific challenge of the SE: Managing identity in order to preserve the attainment of the mission (Tracey and Phillips 2007). For instance, an SE who has mainly worked in the non-profit sector may find it difficult to identify closely with the commercial side of his venture. On the contrary, for entrepreneurs with a for-profit background, the problem is identifying with the goals and approach of the social dimension of their venture, especially when they undermine the economic side (Pharoah et al. 2004). Thus trade-offs between the for-profit and non-profit dimensions, which could create dissonances and interfere with critical processes, should be managed and overcome.

The third difference has to do with how the SV is created. SE seeks long-term social change. As Mair and Martí (2006) state SE's ultimate goal is to alter existing social structures. Thus, it implies making long-term decisions instead of quick-hits and systemic instead of incremental changes (Murphy and Coombes 2009). The SE proposes innovative ways of SV creation which come from the close observation of social problems (Dees 1998), and is grounded in a deep understanding of the constituencies they serve (Murphy and Coombes 2009).

The fourth distinctive feature of SE deals with the process of resource mobilization. SE may face more difficulties in mobilizing financial and human resources. Therefore the SE has to identify funding sources which are primarily interested in creating SV (Austin et al. 2006). The SE should mobilize resources from different and multiple 
sources, which entails mobilizing assets from marginalized groups (Alvord et al. 2004) and leveraging human and financial resources through specific processes such as passion and commitment to the cause (Murphy and Coombes 2009).

Finally, SE presents specific features related to SV creation and distribution, performance measurement and accountability management. How value is created and distributed is a key issue which deals with the very nature of SE as a differentiated phenomenon. While some authors insist that SE ventures require $100 \%$ earned income (Austin et al. 2006; Bosschee and McClurg 2003; Dorado 2006; Thompson and Doherty 2006), others define SE activities as economically sustainable and innovative ventures which generate value -social, economic and cultural- regardless of where revenues come from (Ashoka 2014; Dees 1998; Mair and Martí 2006; Robinson 2006). Closely related, is how SV creation is measured. With regard to performance measurement, different and more idiosyncratic standards of evaluation are required (Austin et al. 2006; Peredo and McLean 2006). Likewise, due to the number and diversity of constituents and stakeholders, managing accountability is quite different for the case of SE. SE must take into consideration additional stakeholders and information needs in order to gain the required legitimacy and reputation (Zander 1993; Cornforth 2003). This issue deals with balancing social and economic objectives, which can create a series of tensions and trade-offs (Pharoah et al. 2004).

These five distinctive features pose two main questions for $\mathrm{SE}$ as a differentiated field of study:

a) The concept of SV. SV is intrinsically linked to the concept of SE, in fact authors like Chell (2007); Austin et al. (2006) and Peredo and McLean (2006) state that it is the central driver of SE. As Dzisi and Otsyina (2014, p.233) state, "generating social value is the explicit, central driving purpose and force for social entrepreneurship". SV creation is the main distinctive feature of SE and the other four distinctive features are related to the first one. However, academic research about SE does not usually offer a definition of SV, and when it is conceptualized; it is poorly defined through broad generic statements. For instance, Peredo and McLean (2006, p.59) state that: 'SE pursues social goals, that is, the desire to benefit society in some way or ways (...) to contribute to the welfare or well-being in a given community'. Likewise, Murphy and Coombes (2009) define SV as generating value for the common good and Certo and Miller (2008) point out that $\mathrm{SV}$ refers to the basic and long-standing needs of society, such as providing food, water, shelter, education and medical services. In the same vein Zahra et al. (2009) cite the concept provided by the Wharton Centre for SE, the NYU Stern and the Fuqua Scholl which define social wealth as 'doing well financially by doing good'. Brickson (2007, p.866) is a little more explicit defining SV 'as that which enhances well-being for the earth and its living organisms'. According to this author, SV should have external and internal dimensions of organization. In the external dimension, related to external stakeholders, it could include things such as wealth generation, innovation and low prices, financial contributions to non-profit organizations, advance and social change, social capital, or 'provide interaction partners with personalization, understanding, and empathy, endowing them with a sense of being inherently valued' (p.874). However, SV could be addressed to clients, or to other large numbers of stakeholders. In this work, we define SV, as the socio- 
economic, cultural and environmental net benefits generated in host destinations by tourism and hospitality developments.

b) The measurement of the SV created by SE. Due to the broadness of the SV concept and its multidimensional, multi-causal, idiosyncratic and non-direct quantifiable nature, SV performance emerges as a research challenge which requires both conceptual and practical advances (Austin et al. 2006). As Certo and Miller (2008, p.267) state: "our understanding of how to measure SV is lacking". Although practices related to social performance measurement and its impact do not represent a 'per se' defining characteristic of SE, which is one of the greatest challenges for practitioners and researchers in SE (Mair and Martí 2006; Lepoutre et al. 2013). The relevance of the issue deals with the fact that all distinctive SE features listed above depend on appropriate performance measurement. If SE does not have proper performance indicators they are unable to manage SV capture and distribution, manage identity and mobilize resources which also require a proper accountability system to report to different stakeholders and balance conflicting social, environmental and economic goals.

With regard to the required SV performance measures, they should be less standardized and more idiosyncratic to the mission (Austin et al. 2006; Peredo and McLean 2006) and to the context where the SE acts (Baker et al. 2005). These performance measures should be meaningful and useful to capture the social impact intended by the SE (Mair and Martí 2006). Also SV performance measures are required which go beyond the view that financial and SV generation are necessarily at odds with one another (Murphy and Coombes 2009), these new measurement propositions should be complementary with the traditional financial measures and as a consequence could be potentially integrated in traditional management systems (Neck et al. 2009).

In order fill the gap of SV measurement, leakage is presented in the following paragraphs as a proper indicator of the amount of SV creation for the case of SE in the hospitality industry.

\section{Social value and its measurement in tourism and hospitality literature}

"Traditional value research has taken a functional, utilitarian view with the value construct measured as the net ratio of benefits to costs" (Williams and Soutar 2009, p.416). Within the tourism literature the concept of "value" is somewhat vague due to the large number and varied uses of the term (Murphy et al. 2000). The same happens for the concept of SV applied to tourism and hospitality research. For instance, in a hotel, the SV concept may be both applied to the tourist (the customers), or to the host residents, but with different perspectives. 1) From the customer's perspective, SV in the literature usually refers to the quality of the product or service captured by this customer, or more specifically the utility acquired by a customer as a result of its association with one or more specific social groups (Sheth et al. 1991), or the hotel. 2) From the host's perspective, SV is related to the benefits provided to the local people. Taking this perspective, SV is linked to the concepts of human welfare, economic growth and development, environmental, heritage and patrimony conservation, health, employment, or education, as we will consider in this paper. In other words, the value created for the host society. In this sense, as social or community goals are the base of 
SE (Harding 2006), and as Abu-Saifan (2012) stresses, the first characteristics of social entrepreneurs is that they are mission driven individuals, dedicated to serve the mission of delivering SV to the underserved, SE is essential for creating SV in hospitality. However, it is necessary to measure this SV created and distributed to the host society.

Nevertheless, the social purpose of Social Entrepreneurs creates greater challenges for measuring performance, which go beyond tangible and quantifiable measures of performance, or the specific financial performance created by their firms. Measuring generated SV is difficult due to non-quantifiability, multicausality, temporal dimensions, and perceptive differences in the social impact created. Performance measurement of SV remains a fundamental differentiator, complicating accountability and even stakeholder relations (Austin et al. 2006). Thus SE may call for quite different standards of evaluation when compared to standard forms of entrepreneurship (Peredo and McLean 2006). However, measurement is necessary. For SE academic literature, one of the critical questions about SV measurement deals with understanding the value generated for the most salient stakeholders, that is, understanding what value is created and for whom (Neck et al. 2009). This is fundamental to managing accountability and sustaining resource mobilization with time. For institutions and policy makers which support SE initiatives, an accurate measurement of SV is also critical in order to differentiate between SE and traditional forms of social activity (Austin et al. 2006; Smith and Stevens 2010). Similarly, SV delineates the distinctiveness and contribution of the SE and differentiates it from traditional corporate social responsibility.

As pointed out before, the relationship between what is socially responsible and economically viable is in need of theoretic elaboration. The difference has long been viewed as a continuum ranging from the social to the economic-financial (Austin et al. 2006; Davis 1973). Although the two poles are presented as a forced trade-off, reality shows that most social activity reflects some economic value, and most economic activity reflects some SV (Murphy and Coombes 2009). Thus, this oversimplified logic can be developed into a more integrative conceptualization which permits concurrent roles for social and financial value. That is, we consider that some measures can simultaneously reflect social and economic value creation.

Due to the complexity and multidimensional nature of SV it is difficult to place a single indicator to measure the contribution made by SE (Weerawardena and Mort 2006). Similarly, due to the social goals of SE, performance dimensions and metrics depend on social mission content and should be idiosyncratic. Thus, SE must identify their own financial and non-financial metrics of success based on mission, industry, and intended social impact (Neck et al. 2009). The problem is that in the hospitality literature the relationship between SE and SV creations is very limited (Dzisi and Otsyina 2014), as there are few studies on SE in this sector and in tourism in general (Austin et al. 2006; Bohdanowicz and Zientara 2008; Ergul and Johnson 2011). Moreover, most of the limited number studies in our sector have mainly focused on developed countries (Dzisi and Otsyina 2014). Hence, the subject of SE is often included within that of corporate social responsibility and environmental management (Ergul and Johnson 2011). Following this perspective, diverse authors have highlighted how SE, through the implementation of diverse policies, could improve the SV created by their firms. For instance, Ergul and Johnson (2011) mention the actions of hotel corporations such as Accord or Kimpton hotels which have stressed their commitment to people, the environment, or community contributions. Holcomb et al. (2007), Bohdanowicz and 
Zientara (2008), and Ergul and Johnson (2011) underline the emphasis of corporate social responsibility of firms such as Starwood hotels, Wyndham, Hilton Hotels Corporation, Marriott, and the Scandic and Rezidor Groups. They also mention some socially responsible activities or policies being developed by hotels, aimed to increase SV creation. However, the SV created by these policies is not measured.

Nevertheless, the literature has offered diverse mechanisms to measure the SV created by tourism or hospitality developments. Some of the most important mechanisms, such as the Keynesian multiplier model, and input-output (I-O) analysis focus on income and employment generation (Archer 1984; Fletcher 1989; Robles-Teigeiro and Díaz 2014; Sinclair and Sutcliffe 1988; Wanhill 1994), and consider indirect and induced effects. Hence, these and other studies using computable general equilibrium modeling show the overall impact of tourism and the derivation of tourism multipliers, but also the effects that tourism has on different industries and patterns of employment (Blake 2008). However, they usually underestimate other benefits, and emphasize benefits more than costs. In addition, as Eagles et al. (2000, p.7) state, "the use of I$\mathrm{O}$ analysis, being a more comprehensive approach, is not feasible at the local level". Moreover, the I-O studies are scarce, because of the lack of suitable databases, being a gap related to the estimation of explicative models of those multipliers (Robles-Teigeiro and Díaz 2014). To overcome these problems, Eagles et al. (2000) also mention other methods used in the literature to analyze the SV generated in protected areas (e.g. Contingent Valuation Method, Hedonic Price Method or the Travel Cost Method). Furthermore, regarding SE, authors such as Harding (2006) and Williams (2007) use techniques such as the Global Entrepreneurship Monitor in order to identify the level of SE activity and the impact of social entrepreneurs in terms of wealth or job creation.

\section{Leakage as a monitoring instrument of social value created by SE}

The following paragraphs are devoted to presenting leakage as an instrument to monitor the SV created by SE activity in the hospitality industry. As the paper shows, leakage indicates both economic and SV creation and is consistent with the characteristics of the industry and environment. But, why we do stress leakage?

We think that apart from being an essential concept to "calculate" an important part of the SV created by hospitality developments, leakage is a crucial mechanism to understand SE behavior at a destination, as a reduced level of leakage can be an indicator of SE activities. This can be concreted when analyzing leakage, not only at a national or local level, but also when calculating leakage at the level of hospitality firms, as was done by Garrigos et al. (2015). In addition, the use of leakage can be a good instrument to frame and measure the effectiveness of different policies addressed to increase SE and generate SV.

Let us focus first on the definition and importance of this concept as a key idea to explain the SV created by SE. Leakage is broadly concerned with "the failure of tourist spending to remain in the destination economy" (Sandbrook 2010, p.125). Following this and Garrigos et al. (2015), we define leakage in hospitality as the amount of revenue generated by guests, which does not remain in the destination economy, and so is not able to create positive SV for tourism destinations.

Leakage is crucial for a proper growth of hospitality, as the economic effects of tourism or hospitality developments are mainly conditioned by the level of leakage 
(Galdon et al. 2013). Moreover, leakage impedes the creation of SV for host societies. Likewise, the existence of Economic leakage is cited as a primary explanation for why tourism does not produce the desired level of economic development (Lacher and Nepal 2010, Pillay and Rogerson 2013), or in general the SV that was supposed to be created. The explanation is that if the industry does not leave significant revenue in host economies (Mbaiwa 2005), and the filtering of its multiplier effects is reduced, the developments associated with tourism and hospitality growth is impeded (Galdon et al. 2013; Garrigos et al. 2000; Haddad et al. 2013), making growth a poor development strategy (Sandbrook 2010), and a weak strategy to generate SV for locals. As Gollub et al. (2003, p.23) state "when leakages occur at unacceptable levels along the value chain, resources are not sustainable", so "tourism's contribution to short and long-term economic growth will fall short of expectations". Leakage can then explain the nongoodness of tourism growth, and the literature has provided numerous examples where tourism has failed to promote local development and improve the livelihood and quality of life of host communities (see Britton 1982; Lacher and Nepal 2010; Mbaiwa 2005; Nyaupane et al. 2006).

Leakage is an essential concept for study due to its high level in some destinations. Nevertheless, the level varies from country to country, according to the size and the development of the economies (Jayawardena and Ramajeesingh 2002). Hence, enclavic tourism destinations usually have extremely high leakages as, in these destinations, most assets are foreign owned and goods are imported from overseas (Britton 1982; Mbaiwa 2005). Moreover leakage has been estimated as $55 \%$ of tourism revenues in developing countries (Boo 1990). However, Jayawardena and Ramajeesingh (2002, p.177), based on data from UNEP, state that for most developed economies, "the average outflow of foreign exchange from tourism is estimated as varying between 10 and 20\%".

Focusing on the hospitality sector, leakage is most often linked to the size of the hotel or the chain and the star-rating. For instance in Bali, in 1977, the amount of import leakage in international standard hotels was estimated at about $40 \%$ while the import leakage of small economy standard hotels was assumed to be about $20 \%$ (Rodenburg 1980). Moreover, in another study also in Bali, Wiranatha and Suryawardani (2013) mention that while the average leakage of all types of hotels was $18.8 \%$ in 2012, tourism leakage was $8.8 \%$ in non-star rated hotels, $12.0 \%$ in 1,2 and 3 star-rated hotels, $22.7 \%$ in 4 and 5 star-rated non-chain hotels, and $51.0 \%$ in 4 and 5 star-rated chain hotels.

Although in most cases, leakages tend to be underestimated (Smith and Jenner 1992), sometimes the calculations of leakage show exaggerated leakage rates (Sandbrook 2010, p.126). This author also advocates the differentiation between national, regional or village level leakage, stressing that "very little attention is usually paid to the issue of scale". Our paper goes further, indicating that leakage should be calculated at the enterprise level, in order to monitor the SV created by the SE. For more details, Garrigos et al. (2015) and Galdon et al. (2013) provide an exhaustive list of direct backward and forward leakages at the hotel level.

However, the concept is very wide, and in order to measure it better, one should try to incorporate different kinds of leakages: foreign exchange leakages, for instance from a foreign-owned hotel to the transnational corporation elsewhere (Hampton 2005), payment to foreigners for management contracts and royalties (Wiranatha and Suryawardani 2013), or foreign investors or banks who finance diverse infrastructures 
and facilities through repatriated earnings, profits, interests and amortization of external debt (Gollub et al. 2003); payments to foreign tour operators and agencies (Wiranatha and Suryawardani 2013); the flow to destination travel on foreign airlines, cruise ships, and other forms of foreign-owned transportations (Gollub et al. 2003); imports of tourism goods or other products or services required to fuel tourism industries (Al-Rimmawi 2003; Pillay and Rogerson 2013; Smith and Jenner 1992); exchange costs for tourism investment, advertising in international marketing and promotion expenditures, commissions paid to foreign banks, credit cards and agencies used by tourists, education abroad and training costs of tourism employees, savings of foreign employees, or even saving of employers, employees, and entrepreneurs left abroad (Wiranatha and Suryawardani 2013); financial leakages, associated with tax avoidance, informal currency exchange transactions, and off-shore investments (Gollub et al. 2003); leakages occasioned by the consumption patterns of nationals to whom wages are initially paid from tourism activities (Smith and Jenner 1992); or even the physical effects of tourism, the depletion, destruction or damage of a country's infrastructure, natural habitats, environments and historical as well as cultural heritage and other assets over time which could negatively impact tourism arrivals and expenditures, lead to the depreciation of a destination's value as an attraction, as well as to the deterioration of the quality of life for local residents (Gollub et al. 2003; Wiranatha and Suryawardani 2013). Other leakages are related to the negative impact on other sectors as they compete for labor, capital, energy infrastructures, and natural resources such as land, water... or even international tourism receipts leading to exchange rate appreciation and consequent declines in other export industries (Blake 2008), making domestic products less competitive and promoting leakage, as their inputs become more expensive (Lacher and Nepal 2010; Torres 2003).

It is also essential to concentrate on the causes that enhance leakage. Some are closely related to the lack of SE in the sector or the economy: the lack of a strong entrepreneurial basis and local ownership in the host industries (Milne 1987); the underdevelopment of the host societies, as "they are poor, uneducated and unfamiliar with the tourism industry" (Lacher and Nepal 2010, p.80); the deficiencies in capital, education, and qualified and skilled employees (Mbaiwa 2005); the inability of the domestic economies to meet the diverse needs of the industry (Jayawardena and Ramajeesingh 2002); the few linkages with the local economy, or local linkages in value chains (Lacher and Nepal 2010; Pillay and Rogerson 2013; Torres 2003); and the lack of good development plans by the local authorities.

All these facts are essential for sustainability, as reflected in the lack of SV creation by tourism and hospitality growth. Moreover, they behave as a bubble of factors which feed-back and contribute to a persistent loss of local control over resources and tourism development, migrant workforce, inefficient appropriation by domestic people of the benefits associated with tourism and hospitality growth, and further high leakages outside the local economy. In addition, these factors seriously reduce the tourism and hospitality industry's potential for generating net financial advantages and growth for the local economies (Andriotis 2002). Furthermore, they have critical consequences for the distribution of income, as these processes lead to situations where the benefits of tourism often accrue to a small subset of the local population, affecting poor people or the local people less in general (Blake 2008; Kiss 2004; Sandbrook 2010). To summarize, leakage is directly reflected not only in the reduction of economic value, but also 
in the lack of SV for the destinations. Hence, we point out that tourism planning should concentrate on achieving goals of development; especially in developing countries, and for the poorest sections of communities (Blake 2008). In order to reach these aims, we think that the focus on leakage as an instrument to measure the results of hospitality planning policies (the SV created), and the promotion of policies related to $\mathrm{SE}$, as a mechanism to get these goals, can provide us with instruments to improve this situation.

\section{Policies to reduce leakage and enhance SE}

The importance of tourism as a catalyst of economic development, prosperity and as a mechanism of poverty alleviation has been debated for decades. The mayor reasons for developing tourism resides in its potential to increase growth in gross domestic product, create employment, increase earnings from foreign exchange, and attract capital investments (Jayawardena and Ramajeesingh 2002; Smith and Jenner 1992). However, leakage of tourism revenue often results in minimal economic and SV benefits for host communities. Let us analyze possible policies, related to hospitality firms, which could reduce the leakage problem and enhance SV through the enhancement of SE.

However, previous to these policies, specific guidelines should be taken into account: a) the social, cultural, environmental and economic characteristic of the destination (Tosun and Timothy 2001); b) the product quality and benefits broadly generated for local people and their acceptance (Jayawardena 2002); c) the level of development of the destination, as it influences the required level of interventionist or entrepreneurial role on the part of the government (Shapley and Knight 2009); d) the consideration of the global, local and firm levels of analysis for policy development. Specifically Garrigos et al. (2015) and Galdon et al. (2013) provide some new ways to calculate and analyze the effects of leakages produced directly by hotels, which are critical to analyze the relevance of SE-; e) the combination of several tourism development approaches, including participatory, comprehensive, integrated, systematic, and incremental/flexible perspectives (Tosun and Timothy 2001).-In particular, the integration of diverse polices is crucial, as well as a comprehensive design with the participation of all the stakeholders involved, including firms (Jayawardena 2002), hotel managers, the tourism industry, central, provincial and local governments, local communities, and even tourists, as their involvement in reducing tourism leakage in the accommodation sector is crucial (Wiranatha and Suryawardani 2013)-.

Nevertheless, let us concentrate on specific procedures. Our framework includes two kinds of policies: those mainly addressing the general environment to reduce general leakage and promote entrepreneurship; and those addressed more at the firm level, and particularly the encouragement of SE.

\section{Policies addressed mainly at the environment to reduce general leakage and promote entrepreneurship}

In our opinion, the policies to be addressed should avoid some of the failed interventionist measures usually applied. The reason is that they have a narrow scope as leakages tend to be associated with long-term variables such as endowments of capital, 
labor and natural resources, institutional capacity, and level of development (Mitchell and Ashley 2007). As Lacher and Nepal (2010, p.80) stress, the main reasons for high leakage are "the lack of capital, local ownership, local employment and inability to link tourism to the local economy". Then, following Andriotis (2002), we think that it is necessary to focus on the encouragement of an entrepreneurial approach to enhance a higher participation of local investors in development, support small-scale hospitality firms, promote employment opportunities for locals, and then reduce leakages from future developments. Concentrating on these and other important actions, in our view the guidelines should include:

1) Better calculation and proper estimation, by government institutions, to assess the true importance of leakage, including the levels, kinds, sources, circumstances, causes, impacts and multiplier effects on different industries, and on patterns of employment (Gollub et al. 2003, Jayawardena 2002). This quantification must be at national level (Blake 2008), but also at regional, local, and hotel level (Garrigos et al. 2015). It is necessary to improve the sources, the calculation and include proper data (Sandbrook 2010), and tourism and hospitality leakage must be placed in context, by comparing its level with the leakage of other sources of income in host economies (in other sectors of the economy, such as agriculture, industry, etc.) as alternative sources of development.

2) The promotion, by government, of alternative or new tourism concepts, such as backpackers and independent travel (Hampton 2005), as developed in the theoretical perspectives of "eco-tourism", "community-based tourism", "pro-poor tourism” (Meyer 2007); small-scale tourism, or Responsible Tourism, as they are associated with lower levels of leakages (Hampton 2005, Lacher and Nepal 2010), they require less capital to enter into business and may have important local economic effects through direct employment, backward linkages, and expenditure multipliers (Hampton 2005). In addition, inside the hotels, governments and hotel managers should try to create "pull marketing strategies", to offer tourists substitutive products to those imported, such as local foods and beverages (Wiranatha and Suryawardani 2013).

3) The broad enhancement of entrepreneurship, as the main facilitator of hospitality development, and the main solution for a broad range of social, economic and political issues (Carmichael and Morrison 2011; Hallak et al. 2012). We posit in general against most of the traditional direct public interventions. The specificities of tourism stress the focus on the managerial processes as the main instruments for development (Al-Rimmawi 2003; Costa and Ferrone 1995) In addition, "entrepreneurship plays a significant role in destination development initiatives by exerting an influence as creative and innovative stakeholders" (Strobl and Peters 2013, p.60), so their specific support is critical.

4) The focus on the creation and development of Small and Medium enterprises, with policies designed by public institutions to facilitate small entrepreneurs with opportunities to create their firms and the access to essential resources, is especially crucial to provide them with capital, credit and other actions to avoid their vulnerability when competing with larger firms (Andriotis 2002; Hampton 2005; Lacher and Nepal 2010). The peculiarities of the hospitality industry also stress the relevance of these actions (Szivas 2001): because the hospitality industry is usually 
dominated by a large number of small firms operating alongside a few large ones (Andriotis 2002); because smaller enterprises tend to be locally owned, managed or controlled (Rodenburg 1980), employ mainly family and locals, supply smaller markets, use local resources and more locally produced goods, and have stronger linkages to local industries (Milne 1987) so reducing leakage; because their development avoids dependence on multinational hospitality chains (Wilkinson 1989), and does not need such costly and sophisticated infrastructures and government expenditures as those required by larger firms (Andriotis 2002).

5) The creation of the conditions and opportunities to allow local people to be employed and participate in the control and the development of the tourism industry, mainly through improvement in training and education. They have to participate in the development of policies, because a participatory approach is essential as it gives better understanding, awareness, and responsibility to minimize tourism leakage in the accommodation sector (Wiranatha and Suryawardani 2013). The need for greater participation by local investors in development is especially essential (Andriotis 2002), as the lack of local involvement often results in high external leakages, and negative effects on employment, investment, and linkages to the local economy (Britton 1982; Hampton 2005). The literature has underlined the existence of a wide number of operational, structural and cultural limitations to participation in tourism (Sandbrook 2010; Tosun 2006). Among them we highlight the lack of education and training, especially at management level (Chowdhury and Shahriar 2012). Leakage is often linked to the domestic capacity to supply skilled staff (Mbaiwa 2005). The lack of proper education, experience and language skills of the local people in general for the tourism jobs, especially for the highest paying jobs (Lacher and Nepal 2010); and the lack of education and experience of local entrepreneurs to manage and run tourism firms, or to market products to foreigners (Nyaupane et al. 2006), impedes the control of tourism development by local communities, undermining their ability to ensure positive outcomes. In addition, alternative solutions such as the restriction of foreign personnel have not proved effective (Gollub et al. 2003), so education and training are essential, and must be promoted by government. In addition, government should encourage hotels which hire a higher proportion of local people, especially in managerial tasks.

Attention to groups of populations which can be affected by the distribution of the profits from tourism, to allow the most equitable distribution of wealth (Tosun and Timothy 2001). Factors such as education, ethnicity, physical location or social networks can constrain access to profits from tourism growth (Ribot and Peluso 2003). In particular, paying attention to socio-cultural, ethnic or racial differences is essential, as they can obstruct linkage formation or consolidation (Pillay and Rogerson 2013; Torres 2003), increasing leakage and reducing SV.

6) The promotion of linkages with domestic sourcing and procurement (Meyer 2007; Scheyvens and Russell 2012), mainly with the development of the value chain of suppliers and demanders. Tourism's potential contribution to the well-being of local communities depends critically upon the growth, consolidation, and strengthening of local economic linkages in the value chain or with other sectors 
(Pillay and Rogerson 2013; Sandbrook 2010), linkages which are often weak, so destinations should increase the amount of connections between tourism and local businesses rather than depend on imported goods and services (Andriotis 2002; Britton 1982; Meyer 2007). In this respect, the necessary integration of the tourism industry into other sectors such as agriculture, industry, transportation, social services, or a wide variety of services is essential. Policies should focus on: Backward linkages -a demand pull concept- (see Blake 2008; Pillay and Rogerson 2013; Pratt 2011; Sinclair 1998; Torres 2003); Forward linkages focusing on the importance of the sector as a supplier to all other sectors- (Blake 2008; Pratt 2011), and even indirect linkages. In this respect, Galdon et al. (2013) and Garrigos et al. (2015) make a list of the most important direct backward and forward linkages at firm level for hotels. In order to increase backward linkages, Valle and Yobesia (2009), and Pratt (2011) stress the importance of streamlining and marketing the different products and also diversifying tourism attractions and activities to spread income and employment opportunities. We should add the importance of promoting the development of the quality and competitiveness of the products of the firms which supply hotels, (for instance fiscally helping the local industries of furniture, hotel design, farmers, cattlemen, fisheries, craftsmen, etc.), and, as we pointed before, the promotion of the partnerships between these firms and the hotels. As for the forward linkages, Gollub et al. (2003) state that leakages should be avoidable by promoting in-country facilities to directly market and make bookings, through marketing consortia and individual establishments. In addition, this author advocates policies addressed to the promotion of hotel finance initiatives, and marketing, for instance with tourism marketing partnerships. Moreover, linkages should not be reduced to the tourism value chain, they must also focus on other sectors which can benefit or be invigorated by the expansion of the tourism sectors, through increasing sales and developing new markets (Lacher and Nepal 2010), infrastructures and a wide variety of facilities, or because of indirect multiplier effects created by the tourism sector, which can be internalized by other industries, or due to the promotion that tourism can bring to other sectors.

\section{Policies addressed at promoting SE behaviors}

Policies should also be addressed to aiding the development of SE activities, and to encourage the managers of the enterprises to behave with a SE perspective, by promoting the attitudes which create SV to the society, or more specifically, should uphold the different features which make entrepreneurs behave as SE. Hence they should:

1) Promote the figure of the entrepreneur or "captain of tourism" (Shaw and Williams 2004, p.132), or broadly entrepreneurship behavior, as a critical issue for destination development (Koh 2006), but in a social way: enhancing risk-tolerance, innovativeness, proactiveness, resource mobilization competences, or in general their behavior towards SV creation. The promotion of local entrepreneurs is essential as they are reported as the most successful at creating positive outcomes 
for hosts (Moscardo 2014), being closer to the attitude of creation of SV and behaving more within the SE perspective.

2) Promote the specific competences of SE inside the firms, by:

- Encouraging SE ventures which aid the development of products, services and outcomes which are desirable and important for the domestic society and which remain unsatisfied by markets or governments (Seelos and Mair 2005). Government authorities should enhance the firms and partnerships when they create SV by specifically supporting: a) The hotels which create more employment, and specifically local employment (to reduce unemployment), b) The hotels which provide their local employees with higher salaries and enhance the education and promotion of local employees, c) The hotels which promote the development of other local industries - the ones that reduce local or firm leakage-, d) The SE's ventures which supply products to hotels, and especially those ventures that are negatively affected by hospitality developments (i.e. agriculture or other industries because of the increase in the prices of resources such as water, land, etc.), or the ones that need to improve the quality and competitiveness of their products to be able to substitute imports, e) The integration of communication between governments, industries, farmers and host communities in order to reduce leakage, f) The associations between local hotels in order to increase their power in their relationships with tour-operators or clients, and to improve the development of the required human and management resources, as well as the development of goods which can substitute imports.

- Helping through fiscal policies, by focusing on non-financial indicators to enhance the firms that promote social goals instead of those which exclusively emphasize for-profit goals. This fact can also facilitate the development of ventures which emphasize social as well as commercial objectives. For instance, and linking with the previous epigraph, in hotels and restaurant encouragement is essential, through hotel managers, of "push marketing strategies" to employ more local products and buy more locally produced goods (Wiranatha and Suryawardani 2013; Milne 1987, Chirenje et al. 2013). These strategies focus on offering local products, therefore hotel managers must create more local menus, or be encouraged to use food or products from the local industries. Managers should change their habits in order to reduce current tourism leakage in the accommodation sector, and these changes should also be promoted by governments with policies such as the creation of fiscal incentives, or distinctive seals (as for example with the promotion of quality) to the hotels more compromised with their local environment, and therefore use more local products.

- Promoting SE attitudes which propose innovative Business Models for SV creation and focus on long-term policies with benefits for the domestic society.

- Enhancing the creation and development of SE which mobilize resources from different and multiple sources, specifically from a broad array of constituents and stakeholders, essentially providing credits to cooperatives of collective initiatives. For instance, some authors such as Nyaupane et al. (2006) stress that local involvement reduces the level of leakage, while Lacher and Nepal (2010) advocate some local-level strategies such as forming-cooperatives, or selling locally made products. 
- Promoting the corporate social responsibility in the hospitality firms. Diverse authors (see Bohdanowicz and Zientara 2008; Ergul and Johnson 2011; Holcomb et al. 2007) mention hotels' socially responsible activities related to wide actions (such as the focus on free trade products and the adoption of environmental initiatives, i.e. some environment restoration programs) which may improve the quality of life of workers down the supply chain, and reduce the hotels' impact on the environment. They also pointed out some forms of charitable activities (donating unwanted linen, furniture and food to local charity organizations or Food Banks, serving food to various youth and parent organizations, assisting people in needs through back to work projects, coaching youths and offering entertainment facilities for the immediate communities...) These SE actions may be developed proactively by the same hotels, as Ergul and Johnson (2011) stress, they can receive benefits from them, including financial and non-financial returns such as the increase in customer loyalty, repeat business, the improvement in communication and the hotel's image, the motivation of stakeholders, and community involvement.

- Strengthening the figure of the social entrepreneur in the local community, and specifically in the enterprises, and provide them with the sociological and psychological instruments necessary to develop their tasks in a social way. To reach this goal, it is necessary to create the social and individual conditions which can help them to grow as entrepreneurs, and specifically to develop as SE. These policies are related to the facts of creating a sense of responsibility at a local level (Lepp 2008), providing the social enterprise and the social entrepreneur with the required legitimacy and reputation (Strobl and Peters 2013), and creating conditions in the communities (Hallak et al. 2012) to strength their required behavior. In this sense the promotion of the human and social capital (Moscardo 2014) needed by the social entrepreneurs, and placing identity on individuals and the entrepreneurial roles in destinations (Koh 2006; Moscardo 2014; Strobl and Peters 2013) is especially important. They are important factors which can strengthen the characteristics, behavior and development of entrepreneurs and therefore the management process (Andriotis 2002). These conditions are critical in order to create an appropriate "social milieu in which entrepreneurs are embedded" (Carmichael and Morrison 2011, p.115), a milieu which has to include psychological connections and social relationships, essential for the generation of the conditions which may ultimately determine a destination's sustainability (Hallak et al. 2012). Governments should emphasize the creation of these conditions essentially within the firms. These should be implemented with actions that go beyond corporate social responsibility, or with the integration of corporate social responsibility, not as a program, but "as a way of living, working and playing that embodies their vision and values", as it was developed in the core values of the SE's venture (Bohdanowicz and Zientara 2008; Ergul and Johnson 2011, p.41)

\section{Conclusion}

This paper has tried to provide an exploratory-theoretical framework to address the challenge of fostering SE and SV measurement in tourism and specifically the hospitality 
industry. The paper proposes leakage as a proper measure of SV creation and as a means to gauge the effectiveness of policies oriented to fostering SE in the hospitality industry.

Defined as the amount of revenue generated by tourists or guests, which does not remain in the destination economy, the determination of causes and consequences of leakage are crucial for destinations and hospitality firms. This is because leakage impedes the possible economic multiplier effects of tourism developments filtering through the economy and stimulating the development of other sectors (Garrigos et al. 2000). Therefore leakage reduction is considered as a proper and idiosyncratic indicator of SE activities in the destinations, and hence an indicator of SV creation (which is essential to improve the quality of life and human development of locals).

The paper shows how the reduction of leakage directly, or indirectly through policies advocated to promote SE, can increase the SV of hospitality growth. In order to reach this goal, the paper analyzes the distinctive figure of the social entrepreneur, their relationship with SV creation, and the links between leakage reduction and SE promotion.

Specifically, this paper stresses that, due to the difficulties surrounding its monitoring, the SV created by the hospitality and tourism development should be measured looking essentially at the level of leakage of the destinations and specifically at that generated by hospitality firms (Garrigos et al. 2015). Following Jayawardena (2002) or Tosun and Timothy (2001), we think that the success of tourism and hospitality developments should not only emphasize the number of tourists; the number of guest nights or even the total amount of money spent by tourists. In our view a complementary and meaningful measurement would be to look at the net tourism receipts (gross profit calculated by deducting all expenditure directly or indirectly related to tourism and foreign exchange leakage), the analysis of these receipts in the multiplier development of other sectors and in the quality of life of host communities. In addition, and apart from the measurement of leakage in our sector, a deep comparison between tourism leakage and leakage generated in other sectors, or by alternative ways of development is needed.

We have to stress, that although leakage only directly measures economic effects, it also indicates the existence of SV creation and an indication of the level of SE activity. The fact is, although some SV is impossible to quantify, the existence of SE monitored through leakage implies that there are individuals and companies which, apart from looking for financial profits, are trying to create SV. One part of this SV is directly measured with leakage, but another part (social, cultural, environmental...) is also monitored indirectly with leakage, as leakage shows the existence of the social behavior of SE in the society.

We are also conscious that leakage is one of the indicators that can be used to measure SV, but obviously it is not the only one, nor can evaluate $100 \%$ of the construct SV. We have already pointed that SV is a wide and multidimensional concept. However, we still think that the use of leakage is essential, as an instrument to monitor the SV created, and that it is adequate in order to measure one significant part of the SV created by the hospitality industry. The important question is that this indicator can allow practitioners to evaluate not only the SV created, but also to frame the policies addressed to promoting SE in the industry. In addition, as the goodness of these policies cannot be evaluated without appropriate indicators, and as it is difficult to find these indicators, the calculation of leakage can positively affect the design and the scope of the policies to be applied. 
Following this perspective, the paper has also created an exploratory framework for promoting empirical courses of action. In this line, the paper proposes diverse strategies and policies which could be implemented to reduce leakage and promote SE in destinations, and therefore increase SV created by hospitality developments. Specifically, this framework concentrates on two diverse groups of procedures: policies addressed directly at creating the environmental conditions to reduce general leakage at destinations, and also policies directed specifically at the enterprises, in order to promote SE behavior in the companies.

Our paper is an initial step to new developments which are needed. Further research should emphasize and expand, with theoretical and empirical works, the analysis and specific characteristics and features surrounding the figure of the social entrepreneur, both in tourism and hospitality, as well as other sectors. In addition, new developments should underline the diverse calculations of leakage as a SV indicator, or the empirical translation between SE behavior and the reduction of leakage, for instance by combining the instruments of Harding (2006), or Williams (2007) and ours. A detailed development of policies addressed to enhance SE, reduce leakage, and promote SV, are also important. To this end, new works could use our framework of polices, developing or improving this framework, or concentrating on and theoretically and empirically developing or testing the relevance of its parts.

\section{References}

Abu-Saifan, S. (2012), Social entrepreneurship: definition and boundaries. Technology Innovation Management Review, February, pp. 22-27.

Al-Rimmawi, H. A. (2003). Palestinian tourism: a period of transition. International Journal of Contemporary Hospitality Management, 15(2), 76-85.

Alvord, S. H., Brown, L. D., \& Letts, C. W. (2004). Social entrepreneurship and societal transformation: an exploratory study. The Journal of Applied Behavioral Science, 40, 260-282.

Andriotis, K. (2002). Scale of hospitality firms and local economic development - evidence from Crete. Tourism Management, 23(4), 333-341.

Archer, B. H. (1984). Economic impact: misleading multipliers. Annals of Tourism Research, 11, 517-518.

Ashoka (2014), Available at http://www.ashoka.org (Accessed 25 April 2014).

Ateljevic, J. (2009). Tourism entrepreneurship and regional development: example from New Zealand. International Journal of Entrepreneurial Behaviour \& Research, 15, 282-308.

Austin, J., Stevenson, H., \& Wei-Skillem, J. (2006). Social and commercial entrepreneurship: same, different, or both? Entrepreneurship: Theory and Practice, 30, 1-22.

Baker, T., Gedjlovic, E., \& Lubatkin, M. (2005). A framework for comparing entrepreneurial processes across nations. Journal of International Business Studies, 36, 492-504.

Blake, A. (2008). Tourism and income distribution in East Africa. International Journal of Tourism Research, 10(6), 511-524.

Bohdanowicz, P., \& Zientara, P. (2008). Hotel companies contribution to improving the quality of life of local commmunities and the well-being of their employees. Tourism and Hospitality Research, 9(2), 147-158.

Boo, E. (1990). Ecotourism: the potentials and pitfalls. Washington DC: World Wildlife Fund.

Bornstein, D., \& Davis, S. (2010). Social entrepreneurship, what everyone needs to know. Oxford: Oxford University Press.

Bosschee, J., \& McClurg, J. (2003). Toward a better understanding of social entrepreneurship: some important distinctions (pp. 1-6). Minnesota: Institute for Social Entrepreneurs.

Brickson, S. L. (2007). Organizational identity orientation: the genesis of the role of the firm and distinct forms of social value. Academy of Management Review, 32(3), 864-888.

Britton, S. G. (1982). The political economy of tourism in the third world. Annals of Tourism Research, 9(3), $331-358$. 
Busenitz, L. W., West, G. P., Shepherd, D., Nelson, T., Chandler, G. N., \& Zacharakis, A. (2003). Entrepreneurship research in emergence: past trends and future directions. Journal of Management, 29(3), 285-308.

Carmichael, B. A., \& Morrison, A. (2011). Tourism entrepreneurship research. Tourism Planning \& Development, 8(2), 115-119.

Certo, S. T., \& Miller, T. (2008). Social entrepreneurship: key issues and concepts. Business Horizons, 51, $267-271$.

Chell, E. (2007). Social enterprise and entrepreneurship, towards a convergent theory of the entrepreneurial process. International Small Business Journal, 25(1), 5-26.

Chell, E., Nicolopoulou, K., \& Karatas-Özkan, M. (2010). Social entrepreneurship and enterprise: international and innovation perspectives. Entrepreneurship \& Regional Development, 22(6), 485-493.

Chirenje, L. I., Chitotombe, J., Gukurume, S., Chazovachii, B., \& Chitongo, L. (2013). The impact of tourism leakages on local economies: a case study of Nyanga District, Zimbabwe. Journal of Human Ecology, 42(1), 9-16.

Chowdhury, M. A. F., \& Shahriar, F. M. (2012). The impact of tourism in a deficit economy: a conceptual model in Bangladesh, perspective. Business Intelligence Journal, 5(1), 163-168.

Cohen, B., \& Winn, M. I. (2007). Market imperfections, opportunity and sustainable entrepreneurship. Journal of Business Venturing, 22(1), 29-49.

Cornforth, C. (Ed.) (2003). The governance of public and nonprofit organizations: what do boards do? London: Routledge.

Costa, J., \& Ferrone, L. (1995). Socio-cultural perspectives on tourism planning and development. International Journal of Contemporary Hospitality Management, 7, 27-35.

Davis, K. (1973). The case for and against business assumption of social responsibilities. Academy of Management Journal, 16, 312-323.

Dees, J. G. (1998). The meaning of "social entrepreneurship" social entrepreneurship founders working group. Fuqua School of Business: Duke University Durham.

Dorado, S. (2006). Social entrepreneurial ventures: different values so different process of creation, no? Journal of Developmental Entrepreneurship, 11, 319-343.

Dzisi, S., \& Otsyina, F. A. (2014). Exploring social entrepreneurship in the hospitality industry. International Journal of Innovative Research and Development, 3(6), 233-241.

Eagles, P. F., McLean, D., \& Stabler, M. J. (2000). Estimating the tourism volume and value in protected areas in Canada and the USA. George Wright Forum, 17(3), 62-76.

Emerson, J. (2003). The blended value proposition: integrating social and financial returns. California Management Review, 45(4), 35-51.

Ergul, M., \& Johnson, C. (2011). Social entrepreneurship in the hospitality and tourism industry: an exploratory approach. Consortium Journal of Hospitality \& Tourism, 16(2), 40-46.

Fletcher, J. E. (1989). Input-output analysis and tourism impact studies. Annals of Tourism Research, 16(4), 514-529.

Foster, W., \& Bradach, J. (2005). Should nonprofits seek profits? Harvard Business Review, 83, 92-100.

Galdon, J. L., Garrigos, F., \& Gil-Pechuan, I. (2013). Leakage, entrepreneurship, and satisfaction in hospitality. The Service Industries Journal, 33(7-8), 759-773.

Garrigos, F., Lapiedra, R. and Narangajavana, Y. (2000), Impacts of Terra Mitica in the Spanish resort of Benidorm. Paper presented at the tourism on islands and specific destinations, 10-14 December, Chios.

Garrigos, F., Galdon, J.L. and Gil (2015), The economic sustainability of tourism growth through leakage calculation. Tourism Economics, 21(4), 721-739.

Gollub, J., Hosier, A., \& Woo, G. (2003). Using cluster-based economic strategy to minimize tourism leakages (pp. 1-56). Madrid: UNWTO.

Haddad, E. A., Porsse, A. A., \& Rabahy, W. (2013). Domestic tourism and regional inequality in Brazil. Tourism Economics, 19(1), 173-186.

Hallak, R., Brown, G., \& Lindsay, N. J. (2012). The place identity-performance relationship among tourism entrepreneurs: a structural equation modeling analysis. Tourism Management, 33(1), 143-154.

Hampton, M. (2005). Heritage, local communities and economic development. Annals of Tourism Research, 32(3), 735-759.

Harding, R. (2006). Social entrepreneurship monitor United Kingdom 2006. London: London Business School.

Hemingway, C. (2005). Personal values as a catalyst for corporate social entrepreneurship. Journal of Business Ethics, 60, 233-249. 
Ho Kang, K., Lee, S., \& Huh, C. (2010). Impacts of positive and negative corporate social responsibility activities on company performance in the hospitality industry. International Journal of Hospitality Management, 29, 72-82.

Holcomb, J. L., Upchurch, R.S. \& Okumus, F. (2007). “Corporate social responsibility: what are top hotel companies reporting?." International Journal of Contemporary Hospitality Management, 19(6), 461-475.

Jayawardena, C. (2002). Mastering Caribbean tourism. International Journal of Contemporary Hospitality Management, 14(2), 88-93.

Jayawardena, C., \& Ramajeesingh, D. (2002). Performance of tourism analysis: a Caribbean perspective. International Journal of Contemporary Hospitality Management, 15(3), 176-179.

Johnson, S. (2000): Literature review on social entrepreneurship. Discussion Paper, the Canadian Centre for Social Entrepreneurship, University of Alberta. http://www.bus.ualberta.ca/ccse/Publications.

Kiss, A. (2004). Is community-based ecotourism a good use of biodiversity conservation funds? Trends in Ecology \& Evolution, 19(5), 232-237.

Koh, K. Y. (2006). Tourism entrepreneurship: people, place, and process. Tourism Analysis, 11(2), 115-131.

Lacher, R. G., \& Nepal, S. K. (2010). From leakages to linkages: local-level strategies for capturing tourism revenue in Northern Thailand. Tourism Geographies, 12(1), 77-99.

Lepoutre, J., Justo, R., Terjesen, S., \& Bosma, N. (2013). Designing a global standardized methodology for measuring social entrepreneurship activity: the global entrepreneurship monitor social entrepreneurship study. Small Business Economics, 40(3), 693-714.

Lepp, A. (2008). Tourism and dependency: an analysis of Bigodi village, Uganda. Tourism Management, 29(6), 1206-1214.

MacMillan, I. C. (2005).Societal Wealth Creation via Experimental Entrepreneurial Philanthropy1 (No. 327). Working paper.

Mair, J., \& Martí, I. (2006). Social entrepreneurship research: a source of explanation, prediction, and delight. Journal of World Business, 41(1), 36-44.

Mair, J., \& Schoen, O. (2007). Successful social entrepreneurial business models in the context of developing economies: an exploratory study. International Journal of Emerging Markets, 2(1), 54-68.

Martin, R. L., \& Osberg, S. (2007). Social entrepreneurship: the case for definition. Stanford Social Innovation Review, 5(2), 28-39.

Mbaiwa, J. E. (2005). Enclave tourism and its socio-economic impacts in the Okavango Delta, Botswana. Tourism Management, 26(2), 157-172.

Meyer, D. (2007). Pro-poor tourism: from leakages to linkages. A conceptual framework for creating linkages between the accommodation sector and 'poor' neighboring communities. Current Issues in Tourism, 10(6), 558-583.

Milne, S. S. (1987). Differential multipliers. Annals of Tourism Research, 14(4), 499-515.

Mitchell, J., and Ashley, C. (2007), Leakage'claims: muddled thinking and bad for policy. ODI Opinion, 81(1), 1-2 .

Mort, G. S., Weerawardena, J., \& Carnegie, K. (2003). Social entrepreneurship: towards conceptualization. International Journal of Nonprofit and Voluntary Sector Marketing, 8(1), 76-89.

Moscardo, G. (2014), Tourism and community leadership in rural regions: linking mobility, entrepreneurship, tourism development and community well-being Tourism Planning \& Development, In press.

Mulgan, G., Tucker, S., Ali, R., \& Sanders, B. (2007). Social innovation. What it is, why it matters and how it can be accelerated. Oxford: Unpublished manuscript.

Murphy, P. J., \& Coombes, S. M. (2009). A model of social entrepreneurship discovery. Journal of Business Ethics, 87, 325-336.

Murphy, P., Pritchard, M. P., \& Smith, B. (2000). The destination product and its impact on traveler perceptions. Tourism Management, 21(1), 43-52.

Neck, H., Brush, C., \& Allen, E. (2009). The landscape of social entrepreneurship. Business Horizons, 52, 13-19.

Nyaupane, G. P., Morais, D. B., \& Dowler, L. (2006). The role of community involvement and number/type of visitors on tourism impacts: a controlled comparison of Annapurna, Nepal and Northwest Yunnan, China. Tourism Management, 27(6), 1373-1385.

Pearce, J., \& Doh, J. P. (2005). The high impact of collaborative social initiatives. MIT Sloan Management Review, 46, 329-339.

Peredo, A. M., \& Chrisman, J. J. (2006). Toward a theory of community-based enterprise. Academy of Management Review, 31(2), 309-328.

Peredo, A. M., \& McLean, M. (2006). Social entrepreneurship: a critical review of the concept. Journal of World Business, 41, 56-65. 
Pharoah, C., Scott, D., \& Fisher, A. (2004). Social enterprise in the balance. Glasgow: Charities Aid Foundation.

Pillay, M., \& Rogerson, C. M. (2013). Agriculture-tourism linkages and pro-poor impacts: the accommodation sector of urban coastal KwaZulu-Natal, South Africa. Applied Geography, 36, 49-58.

Praszkier, R., \& Nowak, A. (2012). Social entrepreneurship. Theory and practice. Cambridge: Cambridge University Press.

Pratt, S. (2011). Economic linkages and impacts across the TALC. Annals of Tourism Research, 38(2), $630-650$.

Ribot, J., \& Peluso, N. (2003). A theory of access. Rural Sociology, 68(2), 153-181.

Robinson, J. (2006). Navigating social and institutional barriers to markets: how social entrepreneurs identify and evaluate opportunities. In J. Mair, J. Robinson, \& K. Hockerts (Eds.), Social entrepreneurship. Basingstoke: Palgrave Macmillan.

Robles-Teigeiro, L., \& Díaz, B. (2014). Estimation of multipliers for the activity of hotels and restaurants. Tourism Management, 40, 27-34.

Rodenburg, E. E. (1980). The effects of scale in economic development: tourism in Bali. Annals of Tourism Research, 7, 177-196.

Russell, R., \& Faulkner, B. (2004). Entrepreneurship, chaos and the tourism area lifecycle. Annals of Tourism Research, 31, 556-579.

Sandbrook, C. G. (2010). Putting leakage in its place: the significance of retained tourism revenue in the local context in rural Uganda. Journal of International Development, 22, 124-136.

Scheyvens, R., \& Russell, M. (2012). Tourism and poverty alleviation in Fiji: comparing the impacts of smalland large-scale tourism enterprises. Journal of Sustainable Tourism, 20(3), 417-436.

Seelos, C., \& Mair, J. (2005). Social entrepreneurship: creating new business models to serve the poor. Business Horizons, 48, 241-246.

Seelos, C., \& Mair, J. (2007). Profitable business models and market creation in the context of deep poverty: a strategic view. Academy of Management Perspectives, 21(4), 49-63.

Shapley, R., \& Knight, M. (2009). Tourism and the state in Cuba: from the past to the future. International Journal of Tourism Research, 11, 241-254.

Shaw, G., \& Williams, A. M. (2004). Critical issues in tourism: a geographical perspective. Oxford: Blackwell.

Sheth, J. N., Newman, B. I., \& Gross, B. L. (1991). Consumption values and market choice. Cincinnati: South Western publishing.

Sinclair, M. T. (1998). Tourism and economic development: a survey. Journal of Development Studies, 34(5), $1-51$.

Sinclair, M. T., \& Sutcliffe, C. M. S. (1988). The estimation of Keynesian income multipliers at the subnational level. Applied Economics, 20(11), 1435-1444.

Smith, C., \& Jenner, P. (1992). The leakage of foreign exchange earnings from tourism. Travel and Tourism Analyst, 3, 52-66.

Smith, B. R., \& Stevens, C. E. (2010). Different types of social entrepreneurship: the role of geography and embeddedness on the measurement and scaling of social value. Entrepreneurship \& Regional Development, 22(6), 575-598.

Strobl, A., \& Peters, M. (2013). Entrepreneurial reputation in destination networks. Annals of Tourism Research, 40, 59-82.

Szivas, E. (2001). Entrance into tourism entrepreneurship: a UK case study. Tourism and Hospitality Research, $3,163-172$.

Tahai, A., \& Meyer, M. J. (1999). A revealed preference study of management journals' direct influences. Strategic Management Journal, 20(3), 279-296.

Thompson, J., \& Doherty, B. (2006). The diverse world of social enterprise. A collection of social enterprise stories. International Journal of Social Economics, 33(5/6), 361-375.

Torres, R. (2003). Linkages between tourism and agriculture in Mexico. Annals of Tourism Research, 30(3), $546-566$.

Tosun, C. (2006). Expected nature of community participation in tourism development. Tourism Management, 27(3), 493-504.

Tosun, C., \& Timothy, D. T. (2001). Shortcomings in planning approaches to tourism development in developing countries: the case of Turkey. International Journal of Contemporary Hospitality Management, 13(7), 352-359.

Tracey, P., \& Phillips, N. (2007). The distinctive challenge of educating social entrepreneurs: a postscript and rejoinder to the special issue on entrepreneurship education. The Academy of Management Learning and Education, 6(2), 264-271. 
UN (1987) World Commission on Environment and Development, Report of the World Commission on Environment and Development: Our Common Future, Annex to General Assembly Document A/42/427.

Valle, E., \& Yobesia, M. N. (2009). Economic contribution of tourism in Kenya. Tourism Analysis, 14(3), 401-414.

Von der Weppen, J., \& Cochrane, J. (2012). Social enterprises in tourism: an exploratory study of operational models and success factors. Journal of Sustainable Tourism, 20(3), 497-511.

Wanhill, S. (1994). The measurement of tourist income multipliers. Tourism Management, 15(4), 281-283.

Weerawardena, J., \& Mort, G. S. (2006). Investigating social entrepreneurship: a multidimensional mode. Journal of World Business, 41, 21-35.

Wilkinson, P. F. (1989). Strategies for tourism in island microstates. Annals of Tourism Research, 16(2), 153-177.

Williams, C. C. (2007). Socio-spatial variations in the nature of entrepreneurship. Journal of Enterprising Communities: People and Places in the Global Economy, 1(1), 27-37.

Williams, P., \& Soutar, G. N. (2009). Value, satisfaction and behavioral intentions in an adventure tourism context. Annals of Tourism Research, 36(3), 413-438.

Wiranatha, A.S., \& Suryawardani, I.G.A.O. (2013). Responsibility of stakeholders in minimizing leakage of tourism industry. A case of Accommodation in Bali, Indonesia. Udayana University, Dempasar-Indonesia

Zahra, S. A., \& Dess, G. G. (2001). Entrepreneurship as a field of research: encouraging dialog and debate. Academy of Management Review, 26(1), 8-10.

Zahra, S. A., Gedajlovic, E., Neubaum, D. O., \& Shulman, J. M. (2009). A typology of social entrepreneurs: motives, search processes and ethical challenges. Journal of Business Venturing, 24, 519-532.

Zander, A. (1993). Making boards effective: the dynamics of nonprofit governing boards. San Francisco: Jossey-Bass. 